\title{
POSITIVE EFFECT OF ETHICAL BEHAVIOR, CORPORATE ETHICAL VALUE, AND IDEALISM IN THE WORKPLACE
}

\author{
Kathelyn ${ }^{1}$, Andi Ina Yustina ${ }^{2 *}$, Setyarini Santosa ${ }^{3}$ \\ 1,2,3 Universitas Presiden, Cikarang - Indonesia \\ Email: kathelynmidelton@yahoo.com
}

KETERANGAN ARTIKEL

Riwayat Artikel

Diterima: 8 November 2019

Direvisi: 15 November 2019

Disetujui: 1 Desember 2019

Klasifikasi JEL: B31, C42, J17

Keywords: Corporate Ethical Value, Ethical Behavior, Idealism, Accountant, Ethics

\section{ABSTRACT}

Accountants who work in a company that adopted an excellent corporate ethical value are believed to have a higher idealism orientation of ethics. This study empirically examines the role of ethical behavior to influence the positive effect of corporate ethical value toward an accountant's idealism. By using a web-based survey, this study spread 100 questionnaires to accountants in Indonesia. The statistical analysis that is used for this research is the Structural Equation Model (SEM) with a Partial Least Squares (PLS) approach. This study result shows that there is a positive relationship between corporate ethical value and idealism, moderate by ethical behavior.

\section{INTRODUCTION}

A lot of prominent accounting scandals that happened in the last decade had attracted considerable attention and impacted a big deal to the profession of an accountant itself. Some prominent cases are always a fruitful topic to discuss, and one of them is the scandal of Enron, which engages in a highly complex series of financial manipulation (McLean, 2001). Along with that, there are continuing accounting scandal which has made a long list of recent major financial irregularities investigation such as Tyco, Xerox, Adelphia, Kmart, Computer Associates, and many else (Gara \& Langstraat, 2003). Those ethical scandals do not only target the financial statement but also the business itself. The example of a business scandal in China in 2008 about a firm that produces baby milk which not worth consumption because the milk was mixed with melamine; this scandal becomes a highlighted business ethics problem in China (Lu, 2009).

Therefore, it is evident that accounting scandals could occur in every organization, which has a destructive effect on the public trust toward an accounting profession, and the long-term damage is still being felt (Brown \& Treviño, 2006). Those cases are pop up to the surface to show one thing that everyone should aware of, which is "ethics."

Ethics is essential because it defines what is wrong and what is right. Business ethics theory confirm when managers faced an ethical decision, they will apply ethical guidelines based on moral philosophies. According to moral philosophies, Idealism is a person's attitude who believes that causing harm to others is always avoidable (Forsyth, 1992). Research has shown that Idealist takes a strict view on the action that could give harm to others, and also being harsher in their judgment of unethical conduct. Idealism belief that high ethical standard and social responsibility are suitable for the performance of the firm and generally correlates with the high ethical decision (Singhapakdi et al. 2000).

The fact that an accountant work in a corporation makes this study believes that the corporate value held by the corporation may 
Kathelyn: Positive Effect of Ethical Behavior ...

influence someone to be an Idealism. Hunt et al. (1986) define the corporate ethical value that as a standard that guides the external adaption and internal integration of organizations. The Sarbanes-Oxley Act in 2002, aimed to create corporate behavior by forming some incentives within the corporate ethical value. Hence there is a significant amount of empirical verification, which reveals that corporate values, expressed in various forms, do indeed affect ethical outcomes. For example, the section of Auditor Independence no 23 about audit partner rotation, which explains that it should be unlawful for the auditor to provide service to the same issuer for more than five years. Therefore, it means that the Sarbanes-Oxley act has formed a supportive law to promote corporate ethical value by issuing an act that explains that a firm must change the auditor after being audit for five years (Singhapakdi et al. 2001).

The previous study has proved that idealism could have made good outcomes for ethics conduct. A study by Singhapakdi et al. (2001) explains that idealism significantly related to ethical intention. Idealism also moderated the effect of corporate ethical value on ethical behavior (Marta et al. 2003). Those previous studies demonstrated that idealism brings a positive impact on other ethical conduct variables.

Therefore, the motivation of this study is to modify the previous research and empirically test the effect of corporate ethical value to idealism because this study having the curiosity about what it could make someone be an idealist person and what could affect an idealist perspective. Ethical behavior becomes the moderating variable that controls a positive relationship between corporate ethical value and idealism. A study by Vitell \& Hidalgo (2006) explains that ethical behavior is positively influenced manager's decision making on choices made when confronted with an ethical dilemma. To encourage ethical conduct within the organization, having ethical behavior on the individual will encourage the development of a personal code of ethics to understand and guide decision making. This study expected to be useful for the public by believing that someone can act ethically as the environment shaped it.

\section{LITERATURE REVIEW}

\section{Corporate Ethical Value}

Hunt et al. (1989) in Vitell \& Hidalgo

(2006) define corporate ethical value as; "A composite of Managers' values, and both the formal and informal policies on ethics of the organization." (p.79)

The composite of the values transferred by the top management to the employee, make corporate ethical value become the dominant parameter that differentiates one firm to another (Chamberlin, 1993). Weaver et al. (1999) in their study of examining the impact of corporate value on ethical beliefs and behavior has revealed that environmental factor leads the organization to implement ethics code. However, this will be achieved if the upperlevel manager guides their implementation and enforcement.

Significant research has also discussed the positive consequences of corporate ethical values. Vitell \& Hidalgo (1988) noted that employees were likely to develop perceptions of the ethical climate of an organization based on its policies, practices, and procedures. Treviño et al. (2006) supported this conclusion and reported that various measures of ethical context were associated with employee behavior and commitment.

Research also showed that high organizational values affect organizational commitment (Hunt et al. 1989), organizational dissent (Valentine et al. 2001), and ethical behavioral intentions (Vitell et al. 2003). Valentine \& Barnett (2002) also argued that unless employees perceived their organization to have high ethical values, ethics codes would not be successful in shaping behavior. 
In conclusion, top-level management has to be able to establish and develop the ethics codes, policies, and programs for the employee being able to perceive that the organization has a high ethical value in purpose for developing ethical behavior conduct in the organization.

\section{Idealism}

Idealism is a person's attitude who believes that causing harm to others is always avoidable (Forsyth, 1992). Research has shown that Idealist takes a strict view on the action that could give harm to others, and also being harsher in their judgment of unethical conduct. Idealist belief that high ethical standard and social responsibility are suitable for the performance of the firm and generally correlates with the high ethical decision (Singhapakdi et al. 2000).

Idealism measures a person's attitude toward causing harm to others. It is always avoidable for idealists to harm another person. They avoid choosing something that will result to give harm or loss to other people (Elias, 2002), Forsyth (1992) explains that a person with low idealist consider moral principle will result in a negative result. Hence, they feel that some harm is often necessary to achieve an overall benefit. Therefore, we can say idealism refers to an inherent interest in the welfare of others and the degree that an intrinsic rightness determines in which behaviors to engage. Thus, we would expect that higher levels of idealism should be associated with lower acceptability of unethical activity.

\section{Ethical Behavior}

Ethical behavior can generally be defined as a behavior that is considered right or wrong, and therefore directs what people should and should not do (Beauchamp \& Bowie, 2000). According to Treviño et al., (2014), ethical behavior refers to the study about both, ethical and unethical decision in whatever the context discussed about. It includes three part of outcomes: accepted moral norm in society, moral standards of society, and beyond society's moral minema (Treviño et al., 2006).

Behavior is considered ethical when it generates better than bad (Hunt \& Vitell, 1986). In the business environment, ethical behavior can be described as fair and honest actions that enable the company to obtain customer satisfaction and develop a long-term relationship with its customers (Roman \& Munuera, 2005).

\section{Hypothesis Development}

\section{Corporate Ethical Value and Individualism}

Singhapakdi et al. (2000) empirically explain that corporate ethical values positively influence an individual's perceptions of the importance of ethics and social responsibility in achieving organizational effectiveness. While the Idealists believe that hurting others is not permissible, therefore they are highly committed to avoiding it (Forsyth, 1992). Meaning that both corporate ethical value and idealism both aim to a better ethics outcome conducting in an organization. Forsyth (1980) explaining that corporate ethical value is realized when top managers speak the formal and informal policies on ethics of the organization to the employee. Made this study believe that when an idealist work in a pleasant environment that develops corporate value, idealism ethical orientation is expected to be supported.

Hunt et al. (1989) state that a strong positive relationship exists between corporate ethical values and organizational commitment. Idealists are not flexible in their moral thoughts, and they find friction between their ethical position and top management ethical ideologies; hence, lower job satisfaction and organizational commitment are expected from them. This corporate ethical value and idealism both correlate with organizational commitment. When an idealist works in a firm with a positive corporate ethical value, the commitment to the organization will be high. 
Based on the above explanation, this study develops a hypothesis as below:

H1: Corporate ethical value positively influences to idealism.

\section{Ethical Behavior, Corporate Ethical Value, and Individualism}

Research found that idealism and ethical judgment of wrongdoing has a positively relationship (Valentine \& Barnett, 2002). To encourage ethical conduct within the organization, ethical behavior is focused on the individual and encourages the development of a personal code of ethics to understand and guide decision making. This study has a sight that, as an idealist, an individual will have a specific ability to judge wrongdoing ethically. When this ability supported by a manager who well communicates the corporate code of ethics, the capacity of the idealism to make an ethical judgment would be supported by the corporate as a whole.

An accountant who has an ethical behavior would adjust her or himself to the situation defined by the firm because the literature believes unless employees find their organization having high ethical values, ethics codes would not be successful in shaping the behavior in the organization (Valentine \& Barnett, 2002). Therefore, as long as the individual itself who perceived that he or she works in a high ethically place and decides to work as ethical behavior, the effort of shaping ethical conduct in the organization could be achieved. Hence this study believes that ethical behavior encourages the development of idealism personal ethics and guide to ethical decision making. Moreover, we firmly believe this hypothesis below:

H2: Ethical Behavior positively moderates the relationship of Corporate Ethical Value toward Idealism.

\section{RESEARCH METHODOLOGY}

\section{Sample and Procedure}

The population of this study was comprised of the different corporations in Indonesia. The respondents used as an individual who works as an accountant, such as Finance, Tax, and Accounting. These criteria needed and would assure that the respondent is the desired sample for this study. The researcher tries to reach the accountant via a website named Linkedln to get in touch with the respondent. The questionnaire given to the respondent has been mixed among each variables' questionnaire, reversed and translated in Indonesian language and stated also the English statement in each questionnaire, in order to assure that each statement question understandable by the respondent, the researcher has been done a pilot test to make sure that the questionnaire indeed easy to read and gain better understand.

\section{Measures}

Hunt et al. (1989) developed the three variables used in this study, Forsyth's Ethics Position questionnaire, and Fu (2013). This study using Corporate Ethical Value (CEV) as an independent variable. In order to measure corporate ethical value, three items of CEV from Hunt et al. (1989) was adopted. One of the items includes "Top Management in my company does not tolerate unethical behavior in the company" Five items Likert scale was used in this research ranging from 1 = strongly disagree to 5 = strongly agree.

The moderating variable for this research was Ethical Behavior (EB). Three statements used to measure the Ethical Behavior adopted from Fu (2013). One of the examples of states that used in this questionnaire was "I do not use company services for personal use" Five items Likert scale was used in this research ranging from 1 = strongly disagree to 5 = strongly agree.

To measure Individualism, the researcher used four items statements which adapted from Forsyth (1980) ethics position questionnaire. "A person should make certain that their actions never intentionally hurt another, even to a small degree" was the example of four statements distributed to 
measure individualism. In measuring this variable, the researcher also used five items Likert scale ranging from 1 = strongly disagree to 5 = strongly agree.

\section{Statistical Analysis}

The statistical analysis for this study is the Structural Equation Model (SEM) with a Partial Least Squares (PLS) approach. SEM-PLS administer method of not only evaluating each of the relationships jointly rather than in separate analyses but also combine the multiitem scales in the analysis to account for any measurement which associates with each of the scales (Hair et al. 2010). Since this SEM-PLS is proficient in handling complex constructs with small amount sample size, this study chose to test all the latent variables which are being hypothesized using SEM-PLS. The software used is version 3.0 of Warp PLS Software.

\section{RESULTS}

\section{Demographic Analysis}

The researcher obtained respondents through social media such as Linkedln and electronic mails to corporate accountants to fill in the questionnaires. The researcher asked about demographic data of the respondents, such as age, gender, department of work, job position, and length of work. From 150 questionnaires deployed, only 100 of them were filled; thus, the response rate in this study is $67 \%$. Of those 100 respondents, $31 \%$ were female, and $69 \%$ were male. The majority of the respondents were having age between 2630 years old is $44 \%$, $25 \%$ were $21-25$ years old, $19 \%$ for respondents at the age of $31-35$ years, $8 \%$ were $35-40$ years old, and only $4 \%$ who is at the age above 40 years old. The job position varied; the highest percentage of $41 \%$ came from a respondent who is a staff employee, the second highest was coming from Assistant manager with $31 \%$, follow with $22 \%$ of the manager, and $2 \%$ of the director. Furthermore, $70 \%$ of them work in the Accounting
Department, $22 \%$ work in the Finance Department, $7 \%$ on Tax Department, 1\% from the audit. With $7 \%$ has been work only less than a year, $62 \%$ of them has been work for 2-5 years, $15 \%$ has been work for $6-10$ years, and more than ten years' work of respondent has $16 \%$, and most of the respondent come from Jakarta. Table below explains overall the detail of respondent.

Table 1. Demographic Data

\begin{tabular}{lr}
\hline & $\%$ \\
\hline Gender: & \\
Male & $69 \%$ \\
Female & $31 \%$ \\
Age: & \\
$20-25$ & $25 \%$ \\
$26-30$ & $44 \%$ \\
$31-35$ & $19 \%$ \\
$36-40$ & $8 \%$ \\
$>40$ & $4 \%$ \\
Experience: & \\
$>1$ year & $7 \%$ \\
$1-5$ year & $62 \%$ \\
6-10 year & $15 \%$ \\
>20 year & $16 \%$ \\
Department: & \\
Accounting & $70 \%$ \\
Finance & $22 \%$ \\
Tax & $7 \%$ \\
Audit & $1 \%$ \\
Position: & \\
Staff & $41 \%$ \\
Assistant Manager & $31 \%$ \\
Manager & $22 \%$ \\
Director & $2 \%$ \\
\hline
\end{tabular}

\section{Measurement Model Analysis}

Validity and Reliability Test

According to Hair et al. (2010), to assess the construct validity, convergent and discriminant validity need to be tested by considering two factors, such as Average Variance Extracted (AVE) and factor loadings. Hair et al. (2010) also explain that the loading value is good if it is higher than five or higher than seven as the ideal value. This study has a good converge, because as Hair et al. (2010) 
Kathelyn: Positive Effect of Ethical Behavior ...

explain that the average variance accepted is 0.5 or above, and the below table demonstrated that this study AVE was ranging from 0.622 to 0.841 , which means this study has a qualified convergent validity of the measurements. The constructs are to be said reliable if the Cronbach's alpha is 0.7 or above (Hair et al., 2019). As the reliability table below showed that Cronbach's alpha for corporate ethical value and idealism is higher than 0.70 , which means the data that is used to test this study, empirically is reliable. Table 2 presented a summary of the above explanation.

Table 2. Reliability and Convergent Validity

\begin{tabular}{|c|c|c|c|}
\hline & Mean & SD & Loading \\
\hline \multicolumn{4}{|c|}{$\begin{array}{l}\text { Reliability }=0.843 ; \text { Cronbach Alpha }=0.720 ; \text { AVE } \\
=0.642)\end{array}$} \\
\hline CEV 1 & 4.52 & 0.59 & $(0.763)$ \\
\hline CEV 2 & 4.79 & 0.43 & $(0.798)$ \\
\hline $\begin{array}{l}\text { CEV } 3 \\
\text { Idealism (I) } \\
\text { Cronbach Al }\end{array}$ & $\begin{array}{c}4.48 \\
\text { (Composite } \\
\text { Ipha = 0.723; A }\end{array}$ & $\begin{array}{c}0.75 \\
\text { Reliability } \\
\text { VE }=\mathbf{0 . 5 4 7}\end{array}$ & $\begin{array}{l}(0.841) \\
=\quad 0.828\end{array}$ \\
\hline 11 & 4.53 & 0.67 & $(0.711)$ \\
\hline 12 & 4.4 & 0.75 & (0.779) \\
\hline 13 & 4.4 & 0.89 & $(0.701)$ \\
\hline 14 & 4.75 & 0.43 & $(0.765)$ \\
\hline \multicolumn{4}{|c|}{$\begin{array}{l}\text { Ethical Behavior (EB) (Composite Reliability = } \\
0.795 ; \text { Cronbach Alpha }=0.612 ; \text { AVE }=0.566 \text { ) }\end{array}$} \\
\hline EB 1 & 4.27 & 1.01 & $(0.812)$ \\
\hline EB 2 & 4.84 & 0.44 & $(0.622)$ \\
\hline EB 3 & 4.8 & 0.51 & $(0.775)$ \\
\hline
\end{tabular}

Source: SEM PLS data result

Discriminant validity is the testing comparable between AVE's squared roots with the constructs. Table 3 below presented that the AVE's squared roots are higher than the correlation between the latent variable, each on the column. Thus, it means that the discriminant validity test is adequate. Table 3 presented a summary of the above explanation.
1. Corporate Ethical Value (CEV) (0.801)

2. Idealism (I) $\quad 0.453$

$\begin{array}{llll}\text { 3. Ethical Behavior (EB) } & -0.225 & -0.454 & \text { (0.752) }\end{array}$

Source: SEM PLS data result

Diagonal element: square root of AVE; offdiagonal: correlation

Descriptive statistic and correlation table below demonstrate the mean and standard deviation of the variables that express the study hypothesis, which is all supported, with the fact that it indicates corporate ethical values has positive influence toward idealism, because it has 0.406 of path coefficient that significant at $p<0.01$. Ethical behavior moderates the relationship between corporate ethical value and idealism with a 0.209 path coefficient that significant at $p<0.1$. Table 4 presented a summary of the above explanation.

Table 4. Descriptive statistics correlations

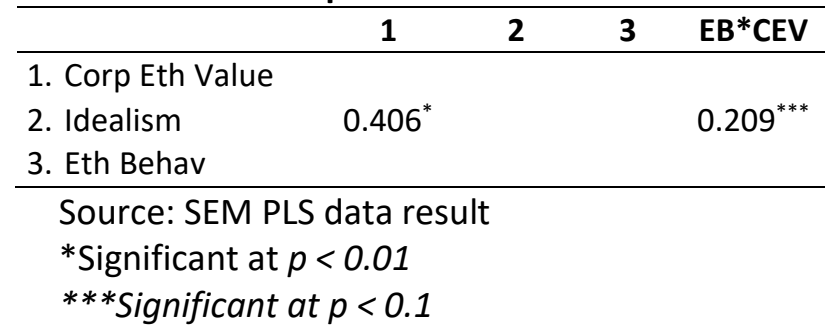

The results shows that all the hypothesis developed are supported, as the result demonstrated that this study has $(\beta=0.41, p<$ $0.01)$ for the relationship of corporate ethical value and idealism and has $(\beta=0.21, p=0.08)$ for the moderation role of ethical behavior to the relationship of the corporate ethical value and idealism.

Those beta values and $p$-value mean that there is a significant impact of corporate ethical value toward idealism, with the R-squared of 0.27 , which means that corporate ethical value might affect $27 \%$ to idealism. Figure 1 presented a summary of the above explanation.
Table 3. Discriminant Validity 


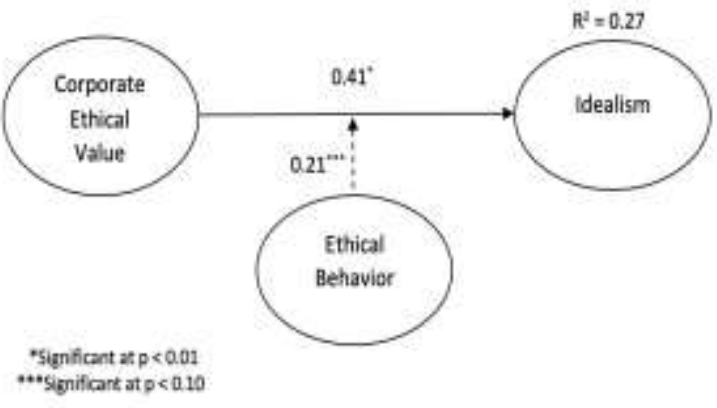

Figure 1. Full model and Result

\section{Discussion}

This study proposes and examines the relationship between corporate ethical value and idealism. This study also examines the moderation role of ethical behavior to control the positive effect of corporate ethical value to idealism. Based on the results, all the hypotheses are supported. The first finding is that there is a significant relationship between corporate ethical value and idealism. When the top-level management establishes and develops the ethics codes, policies, and programs for the employee to be able to perceive that the organization has high ethical values. Made this study believe that when an idealist work in a pleasant environment that develops corporate value, idealism ethical orientation is expected to be supported. This result is in line with what Forsyth (1992) asserted that the determinant of an individual behavior when facing an ethical issue is their ethical perspective.

The second finding shows the hypothesis of ethical behavior moderation is also supported. That relationship is in line with what Valentine \& Barnett (2002) explain that an accountant who has an ethical behavior would adjust her or himself to the situation defined by the firm because the literature believes unless employees perceived their organization to have high ethical values, ethics codes would not be successful in shaping behavior. Hence this is parallel with the study findings that ethical behavior encourages the development of idealism personal ethics and guide to ethical decision making.

\section{CONCLUSIONS}

This study is empirically testing the relationship between corporate ethical values that hypotheses have a positive influence on idealism, moderated by ethical behavior. By using 100 samples of accountants in Indonesia, this study tests the variables by using a questionnaire developed by Forsyth (1980), Hunt, et al. (1989), and Fu (2013). All the hypotheses are supported after the result revealed by testing it using Structural Equation Modeling-Partial Least Square (SEM-PLS) processing data software.

The results show that there is a positive influence of corporate ethical value to idealism. The idea is that corporate ethical value and idealism are both aim to a better ethics outcome conducting in an organization. Forsyth (1980) explaining that corporate ethical value is realized when top managers speak the formal and informal policies on ethics of the organization to the employee. When an idealist work in a pleasant environment that develops corporate value, idealism is supported. Ethical behavior moderates the correlation of the relationship between corporate ethical value and idealism because the theory explains that idealists will have an unerring ability to judge wrongdoing ethically. When this ability supported by a manager who well communicates the corporate code of ethics, the capacity of the idealism to make an ethical judgment would be supported by the corporate as a whole, ethical behavior would encourage the development of idealism personal ethics and guide to an ethical decision making.

Based on the result, this study has implications, and as theoretical implication, this study provides evidence that ethical behavior moderated a positive correlation of corporate ethical value toward idealism. The study gives us insight that code of ethics may 
facilitate self-development of idealism ethical orientation in an organization as a sign of an excellent ethical outcome and decision making by an accountant. The fact that corporate value could lead an individual's idealism will result in a better ethically decision outcome made by an accountant. The result sharpens our understanding regarding the importance of ethical conduct policy development in the organization. It might add up to business ethics and behavioral literature research or books for future knowledge.

On the other hand, regarding practical implication, the finding of this study demonstrates corporate ethical value have an essential role in an organization, specifically for enhancing an ethical intention and develop the perspective of idealism based on its policies, practices, and procedures. To management, the level can start with guiding the implementation of ethics codes and programs in the organization. This finding is in line with what Weaver et al. (1999) explained when they examined the source of an organization's ethical environment. They found that environmental factors could result in better implement ethics codes and programs in the organization; this would be achieved if the upper-level managers guide their implementation and enforcement. The focus should be on delineating what the corporation believes is right, with clearly communicated management support, and maybe rewarding the right behavior within those guidelines. This implication expected to have a role in the mitigating scandal in accounting and business ethics.

This research has subject to several limitations that should be highlighted. First, this study only collected and used 100 samples of the respondent in Indonesia. Future research needs to examine these theories in a bigger sample size for more generalize and reliable data.

Second, the result shows that the Cronbach's alpha of ethical behavior is below 0,7 that the result only has 0,612 as described in table 5; this is a quite low Cronbach alpha. Hence, we cannot rely on reliable data resulted from ethical behavior. Thus, future research should re-examine this study by extending the current research model to get a higher value of Cronbach's alpha.

Third, there was a possibility that there was response biased had affected the data. According to Podsakoff et al. (2003), to control the response biased from respondents, the study may separate the measurement for independent variable from the measurement of dependent variable, thus this resulting a time lag in spreading the questionnaire, because the data collected at two different times and the respondent should be the same. However, due to lack of time, the researcher cannot conduct that way, thus cannot avoid that standard method variance that may affect the data collection. Therefore, this study recommends future research to do this to avoid response bias for their data.

Fourth, this study using students from the university to do the pilot test to test the questionnaire before deliver it to the respondent, which made this study subject to limitation, because student only able to provide feedback in the form of revising wording only not the content of the questionnaire, and no substantial suggestions were provided. Therefore, the further study is expected to have tested the questionnaire to the real respondent to get good feedback and suggestions.

For future research, it is suggested that this model of this study could also be empirically tested using another method, such as face to face interview, or we can say an experiment. Because research methodology is not limited only to the questionnaire surveybased, the result could be different if the method being used is different.

There may be an underlying assumption, in ethics research, that ethics decisions in the company are made by teams rather than individuals (Marta et al. 2011), but this study was unaware of any work to test that 
assumption. Future research might examine the dynamics of group interaction and the role of CEV and moral perspectives informing ethical behavior and compare those effects to individual ones.

\section{REFERENCES}

Beauchamp, T. \& Bowie, N. (2000). Ethical Theory and Business, 6th ed., PrenticeHall. Englewood Cliffs, NJ.

Brown, M. E., \& Treviño, L. K. (2006). Ethical leadership: A review and future directions. The Leadership Quarterly, 17(6), 595-616.

Chamberlin, E. H. (1933). The Theory of Monopolistic Competition. Cambridge. MA: Harvard University Press.

Elias, R.Z. (2002). Determinants of earnings management ethics among accountants. Journal of Business Ethics, 40, 33-45.

Hair, J. F., Risher, J. J., Sarstedt, M., \& Ringle, C. M. (2019). When to use and how to report the results of PLS-SEM. European Business Review, 31(1), 2-24.

Forsyth, D. (1980). A taxonomy of ethical ideologies. Journal of Personality and Social Psychology, 39, 175-184.

Forsyth, D. (1992). Judging the morality of business practices: The influence of personal moral philosophies. Journal of Business Ethics, 11, 461 - 470.

$\mathrm{Fu}$, W. (2013). The impact of emotional intelligence, organizational commitment, and job satisfaction on the ethical behavior of Chinese employees. Journal of Business Ethics, 122(1), 137144.

Gara, S. \& Langstraat, C. (2003). The SarbanesOxley act of 2002: A new ballgame for accountants. University of Memphis Law Review, 34, 73-114.

Hair, J. F., Black, W. C., Babin, B. J., \& Anderson, R. E. (2010). Multivariate Data Analysis, 7th Edition. Edinburg: Pearson.

Hair, J. F., Sarstedt, M., Hopkins, L., \& G. Kuppelwieser, V. (2014). Partial least squares structural equation modeling (PLS-SEM). European Business Review, 26(2), 106-121.

Hunt, S. D., \& Vitell, S. (1986). A general theory of marketing ethics. Journal of Macro marketing, 6(1), 5-16.

Hunt, S.D., Wood, V. \& Chonko, L.B. (1989). Corporate ethical values and organizational commitment to marketing. Journal of Marketing, 53:7990.

Lu, X. (2009). A Chinese perspective: Business ethics in China now and in the future. Journal of Business Ethics, 86, 451-461.

Marta, J. K. M., Attia, A., Singhapakdi, A., \& Atteya, N. (2003). A comparison of ethical perceptions and moral philosophies of American and Egyptian business students. Teaching Business Ethics, 7, 1-20.

Marta, J., Singhapakdi, A., Lee, D., Burnaz, S., Ilker Topcu, Y., Serap Atakan, M. G., \& Ozkaracalar, T. (2011). The effects of corporate ethical values and personal moral philosophies on ethical intentions in selling situations: Evidence from Turkish, Thai, and American businesspeople. Journal of Business Ethics, 106 (2), 229-241.

McLean, B. (2001). Why Enron went bust. Forbes, 24 December, pp. 58-65.

Podsakoff, P. M., S. B. MacKenzie, J. Lee, \& N. P. Podsakoff. (2003). Common method biases in behavioral research: A critical review of the literature and recommended remedies. Journal of Applied Psychology, 88 (5), 879-903.

Román, S., \& Munuera, J. (2005). Determinants and consequences of ethical behavior: an empirical study of salespeople. European Journal of Marketing, 39(5/6), 473-495.

Singhapakdi, A., Salyachivin, S., Virakul, B., \& Veerayangkur, V. (2000). Some important factors underlying ethical decision making of managers in Thailand. 
Kathelyn: Positive Effect of Ethical Behavior ...

Journal of Business Ethics, 27(3), 271284.

Singhapakdi, A., Marta, J. K. M., Rao, C. P., \& Cicic, M. (2001). Is cross-cultural similarity an indicator of similar marketing ethics? Journal of Business Ethics, 32(1), 55-68.

Treviño, L. K., Weaver, G. R., \& Reynolds, S, J. (2006). Behavioral ethics in organizations: A review. Journal of Management, 32(6), 951-990.

Treviño, L. K., Nieuwenboer, N. A., \& KishGephart, J. J. (2014). (Un)Ethical behavior in organizations. Annual Review of Psychology, 65, 635-660.

Valentine, S. \& Barnett, T. (2002). Ethics codes and sales professionals' perceptions of their organizations' ethical values. Journal of Business Ethics, 40, 191-200.

Valentine, S., Young, K., Bailey, L., Barhoum, N., LaBure, Glover, N., \& Isaac, P. (2001). Expressing organizational dissent: The role of ethical ideology and corporate ethical values. Journal of Business Strategies, 18,71-89.

Vitell, S.J., Bakir, A., Paolillo, J.G.P., Hidalgo, E.R., Al-Khatib, J., \& Rawwas, M.Y.A. (2003). Ethical judgments and intentions: A multinational study of marketing professionals. Business Ethics: A European Review, 12(2), 151-171.

Vitell, S.J., \& Hidalgo, E.R. (2006). The impact of corporate ethical values and enforcement of ethical codes on the perceived importance of ethics in business: A comparison of U.S. and Spanish Manager? Journal of Business Ethics, 64(1), 31-43.

Weaver, G.R., Trevino, L.K. \& Cochran, P.L. (1999). Corporate ethics programs as control systems: influences of executive commitment and environmental factors. Academy of Management Journal, 42 (1), 41-57. 